\title{
Ancestral Caddo Ceramic Vessels from the Tom Shumate Site (41RK2), Rusk County, Texas
}

Timothy K. Perttula

Heritage Research Center, Stephen F. Austin State University

Follow this and additional works at: https://scholarworks.sfasu.edu/ita

Part of the American Material Culture Commons, Archaeological Anthropology Commons, Environmental Studies Commons, Other American Studies Commons, Other Arts and Humanities Commons, Other History of Art, Architecture, and Archaeology Commons, and the United States History Commons

Tell us how this article helped you.

This Article is brought to you for free and open access by the Center for Regional Heritage Research at SFA ScholarWorks. It has been accepted for inclusion in Index of Texas Archaeology: Open Access Gray Literature from the Lone Star State by an authorized editor of SFA ScholarWorks. For more information, please contact cdsscholarworks@sfasu.edu. 


\section{Ancestral Caddo Ceramic Vessels from the Tom Shumate Site (41RK2), Rusk County, Texas}

\section{Creative Commons License}

\section{(c) (1) \&}

This work is licensed under a Creative Commons Attribution-NonCommercial 4.0 International License 


\title{
Ancestral Caddo Ceramic Vessels from the Tom Shumate Site (41RK2), Rusk County, Texas
}

\author{
Timothy K. Perttula
}

\section{Introduction}

The subject of this article are the four ancestral Caddo ceramic vessels from the Tom Shumate site (41RK2) in Rusk County. The site is on Dry Creek in the upper Angelina River basin, about 5 $\mathrm{km}$ southeast of the town of Mount Enterprise, Texas (Figure 1). The ceramic vessels were found by the landowner after a flood in April 1935 had exposed a burial feature. Later work in 1935 by The University of Texas at Austin, led by A. T. Jackson, recovered no additional burial features; Jackson purchased the vessels from the landowner.

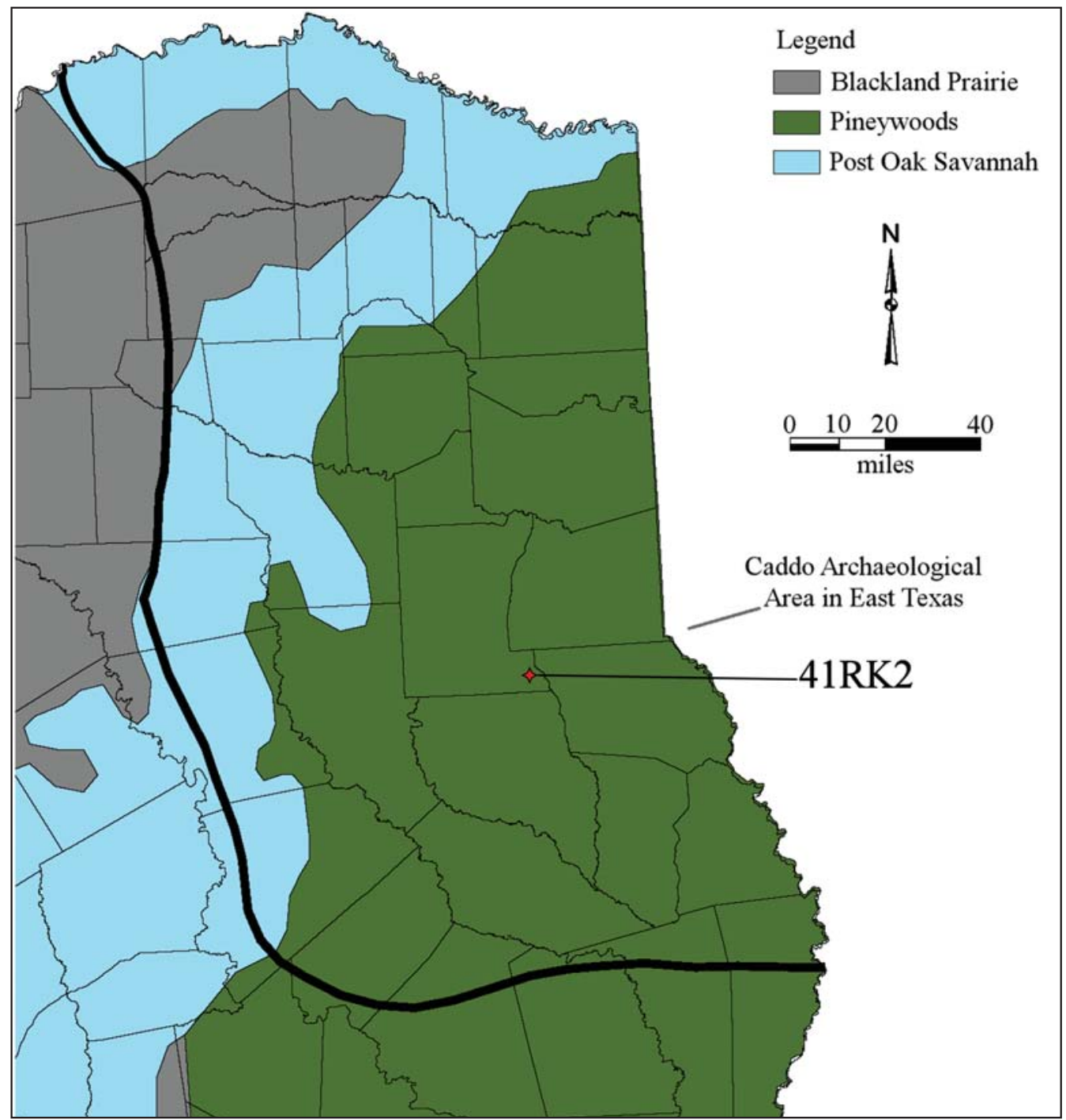

Figure 1. The location of the Tom Shumate site (41RK2) in East Texas. 


\section{Ceramic Vessels}

Three of the vessels had been placed along the west side of the grave, but the location of the fourth vessel (a jar) relative to the rest of the burial feature is not known. The four vessels include a carinated bowl, a bowl, a bottle, and a jar; each has a distinct set of decorative elements.

SITE NAME OR SITE NUMBER: Tom Shumate (41RK2)

VESSEL NO.: 1

VESSEL FORM: Carinated bowl

NON-PLASTICS AND PASTE: grog

RIM AND LIP FORM: Direct rim and a rounded lip

CORE COLOR: F (fired in a reducing environment and cooled in the open air)

INTERIOR SURFACE COLOR: reddish-brown; fire clouds on the base

EXTERIOR SURFACE COLOR: reddish-brown; fire clouds on the base

WALL THICKNESS (IN MM): rim, $6.1 \mathrm{~mm}$

INTERIOR SURFACE TREATMENT: smoothed

EXTERIOR SURFACE TREATMENT: smoothed

HEIGHT (IN CM): 6.0

ORIFICE DIAMETER (IN CM): 12.7

DIAMETER AT BOTTOM OF RIM OR NECK (IN CM): 12.7

BASE DIAMETER (IN CM) AND SHAPE OF BASE: 8.0; circular and flat

ESTIMATED VOLUME (IN LITERS): 0.46

DECORATION (INCLUDING MOTIF AND ELEMENTS WHEN APPARENT): There are two widelyspaced horizontal engraved lines on the vessel rim

PIGMENT USE AND LOCATION ON VESSEL: none

TYPE AND VARIETY (IF KNOWN): Hickory Engraved 
SITE NAME OR SITE NUMBER: Tom Shumate (41RK2)

VESSEL NO.: 2

VESSEL FORM: Bowl

NON-PLASTICS AND PASTE: grog

RIM AND LIP FORM: Direct rim and rounded lip

CORE COLOR: $\mathrm{F}$ (fired in a reducing environment and cooled in the open air)

INTERIOR SURFACE COLOR: reddish-brown; fire clouds on the body and base

EXTERIOR SURFACE COLOR: reddish-brown; fire clouds on the base

WALL THICKNESS (IN MM): rim, $6.8 \mathrm{~mm}$

INTERIOR SURFACE TREATMENT: none

EXTERIOR SURFACE TREATMENT: smoothed

HEIGHT (IN CM): 5.7

ORIFICE DIAMETER (IN CM): 12.7

DIAMETER AT BOTTOM OF RIM OR NECK (IN CM): N/A

BASE DIAMETER (IN CM) AND SHAPE OF BASE: 6.6; circular and flat

ESTIMATED VOLUME (IN LITERS): 0.29

DECORATION (INCLUDING MOTIF AND ELEMENTS WHEN APPARENT): The vessel rim and body has a series of diagonal engraved lines pitched in opposite directions around a large open triangle element, as well as a series of curvilinear engraved lines (Figure 2).

PIGMENT USE AND LOCATION ON VESSEL: none

TYPE AND VARIETY (IF KNOWN): Unidentified fine ware

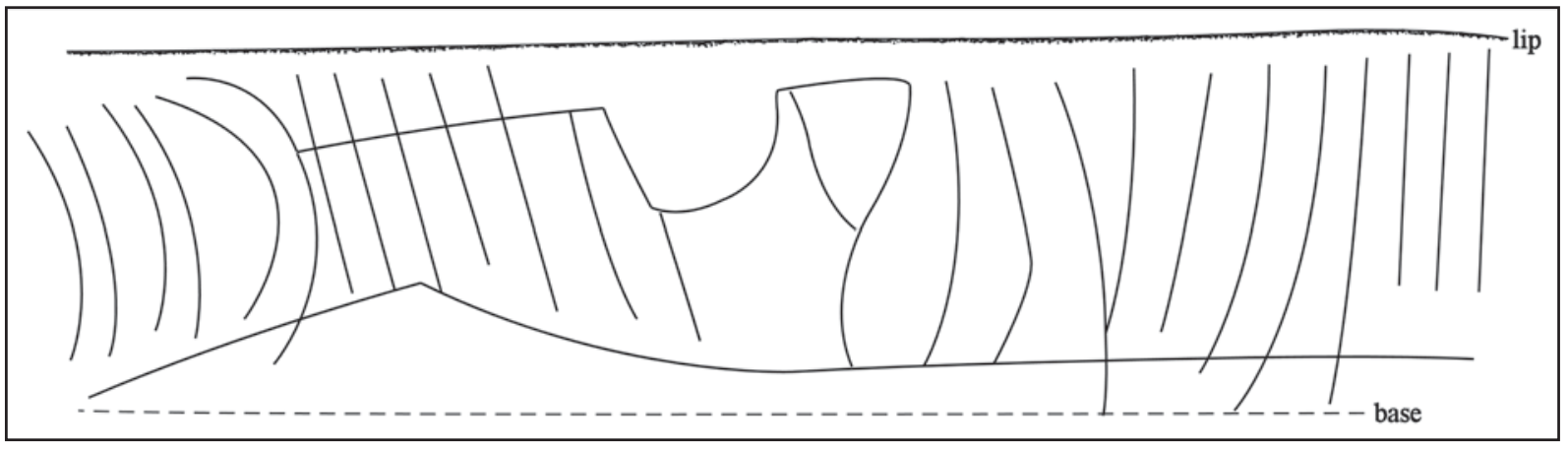

Figure 2. Decorative elements on engraved bowl from the Tom Shumate site (Vessel 2). 
SITE NAME OR SITE NUMBER: Tom Shumate (41RK2)

VESSEL NO.: 3

VESSEL FORM: Bottle

NON-PLASTICS AND PASTE: bone and hematite

RIM AND LIP FORM: N/A

CORE COLOR: G (fired in a reducing environment and cooled in the open air)

INTERIOR SURFACE COLOR: gray

EXTERIOR SURFACE COLOR: reddish-brown; fire clouds on the base

WALL THICKNESS (IN MM): body, $5.3 \mathrm{~mm}$

INTERIOR SURFACE TREATMENT: none

EXTERIOR SURFACE TREATMENT: smoothed

HEIGHT (IN CM): 8.9+

ORIFICE DIAMETER (IN CM): 10.1

DIAMETER AT BOTTOM OF RIM OR NECK (IN CM): N/A

BASE DIAMETER (IN CM) AND SHAPE OF BASE: 7.7; circular and flat

ESTIMATED VOLUME (IN LITERS): 0.36

DECORATION (INCLUDING MOTIF AND ELEMENTS WHEN APPARENT): The vessel body has three diagonal engraved zones filled with diagonal hatched engraved lines (Figure 3).

PIGMENT USE AND LOCATION ON VESSEL: none

TYPE AND VARIETY (IF KNOWN):

Unidentified fine ware

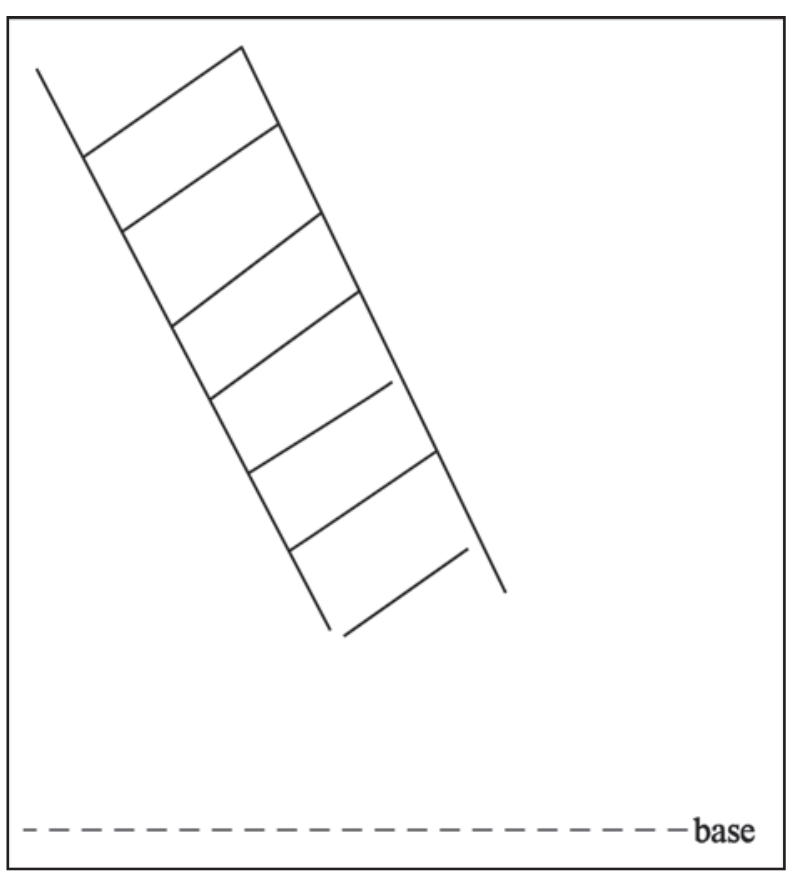

Figure 3. Decorative elements on Vessel 3 from the Tom Shumate site.

SITE NAME OR SITE NUMBER: Tom Shumate (41RK2)

VESSEL NO.: 7

VESSEL FORM: Jar

NON-PLASTICS AND PASTE: grog 
RIM AND LIP FORM: Everted rim and rounded lip

CORE COLOR: $\mathrm{G}$ (fired in a reducing environment and cooled in the open air)

INTERIOR SURFACE COLOR: black

EXTERIOR SURFACE COLOR: light brown; fire clouds on the rim and body; charred organic remains and sooting on the rim and body

WALL THICKNESS (IN MM): rim, $7.9 \mathrm{~mm}$

INTERIOR SURFACE TREATMENT: smoothed

EXTERIOR SURFACE TREATMENT: smoothed on the vessel body

HEIGHT (IN CM): 18.4

ORIFICE DIAMETER (IN CM): 15.2

DIAMETER AT BOTTOM OF RIM OR NECK (IN CM): 13.4

BASE DIAMETER (IN CM) AND SHAPE OF BASE: 8.4; circular and flat

ESTIMATED VOLUME (IN LITERS): 2.5

DECORATION (INCLUDING MOTIF AND ELEMENTS WHEN APPARENT): The rim has nine sets of stacked incised triangles filled with tool punctations (Figure 4).

PIGMENT USE AND LOCATION ON VESSEL: none

TYPE AND VARIETY (IF KNOWN): Pennington Punctated-Incised (see Suhm and Jelks 1962:Plate 61j)

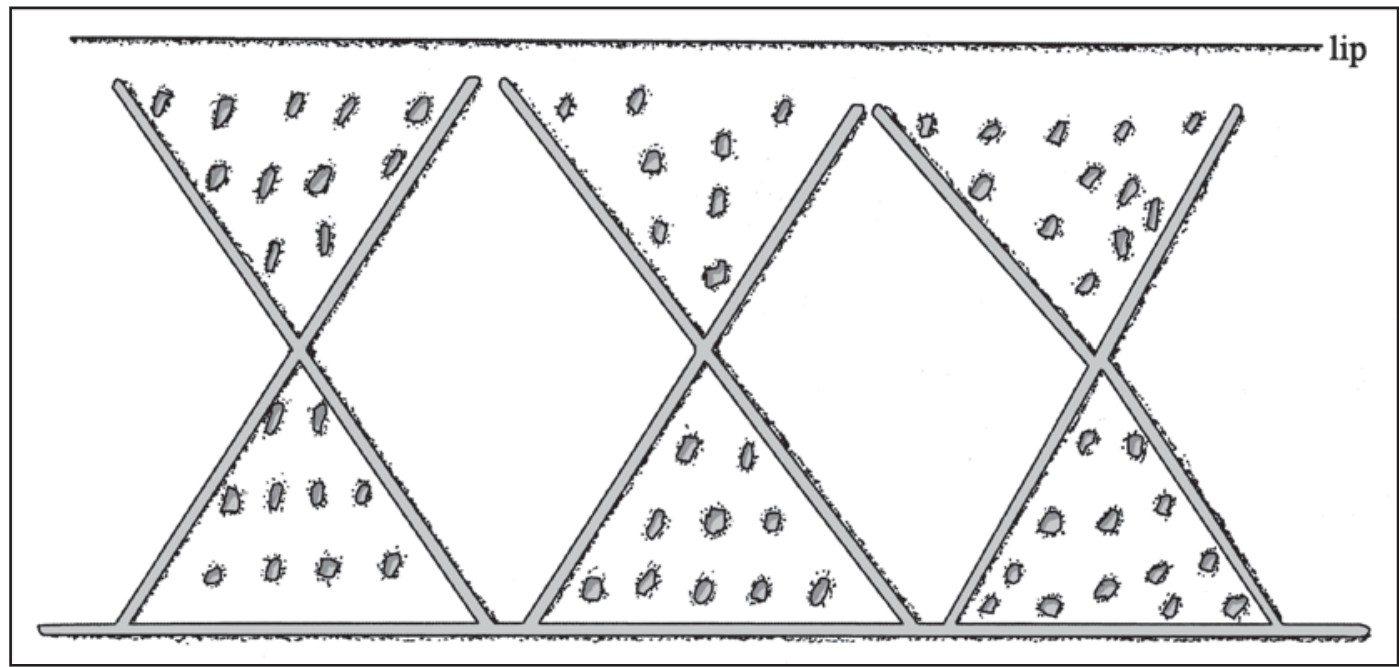

Figure 4. Decorative elements on Vessel 4 from the Tom Shumate site. 


\section{Summary and Conclusions}

Flooding along Dry Creek in the Angelina River basin in 1935 exposed an ancestral Caddo burial feature with several associated ceramic vessels. The landowner, Tom Shumate, recovered the vessels, which were subsequently purchased by The University of Texas (UT) in September 1935. UT excavations at the site in 1935 failed to identify any additional Caddo burial features or associated ceramic vessels.

The four vessels in the grave of one ancestral Caddo burial at the site include single examples of a grog-tempered carinated bowl, a bowl, and a jar; the one bottle in the collection was tempered with crushed bone and hematite. The vessels were uniformly fired in a reducing environment and cooled in the open air, and ranged from small to medium-sized. Two of the decorated vessels can be identified to ca. A.D. 1000-1200 ceramic types, namely a Hickory Engraved carinated bowl and a Pennington Punctated-Incised jar, indicating the Caddo burial dates to this temporal period. The other two vessels have engraved decorative elements consistent with an Early Caddo period age in East Texas, including the bowl with diagonal and concentric curvilinear lines and a bottle with diagonal hatched zones.

\section{Acknowledgments}

Thanks to Marybeth Tomka for providing access to the Tom Shumate site ceramic vessels in the collections of the Texas Archeological Research Laboratory at The University of Texas at Austin. Lance Trask prepared the figures in this article.

\section{References Cited}

Suhm, D. A. and E. B. Jelks (editors)

1962 Handbook of Texas Archeology: Type Descriptions. Special Publication No. 1, Texas Archeological Society, and Bulletin No. 4, Texas Memorial Museum, Austin. Reprinted in 2009, Gustav's Library, Davenport, Iowa. 